\title{
Digital Comic Media for Teaching Secondary School Science
}

\author{
https://doi.org/10.3991/ijim.v16i03.28967
}

\author{
Habiddin Habiddin ${ }^{1}$, Muhammad Ashar ${ }^{2(\mathbb{})}$, Achmad Hamdan ${ }^{3}$, Khaidir R Nasir ${ }^{3}$ \\ ${ }^{1}$ Department of Chemistry, Universitas Negeri Malang, Malang, Indonesia \\ ${ }^{2}$ PUIPT Disruptive Learning Innovation, Universitas Negeri Malang, Malang, Indonesia \\ ${ }^{3}$ Department of Electrical Engineering, Universitas Negeri Malang, Malang, Indonesia \\ Muhammad.ashar.ft@um.ac.id
}

\begin{abstract}
The rapid development of science and technology in the $21 \mathrm{st}$ Century demands students (both school and university) to hold sufficient skills, including critical thinking and problem solving, to compete globally. Educational systems are responsible for promoting the skills through the teaching and learning experiences, including teaching material and learning media applied in the class. This paper highlights the development of mobile apps-based digital comic media in social learning that can be integrated into personalized online learning. The steps to develop the media was applied the Gay's procedure. The digital comic media present an interactive science knowledge platform in the form of digital comic media enriched with Augmented reality technology. The media has been tested to 20 students during the emerging of the Covid-19 pandemic and showing good acceptance. This implies that digital comic media is of value to be used and applied in online learning.
\end{abstract}

Keywords-digital comics media, augmented reality, teaching science

\section{$1 \quad$ Introduction}

Education plays an essential role in shaping the character of the nation's future generations. The success of teaching and learning is affected by the availability of adequate learning resources, including modules and textbooks, learning media, as well as the teaching skills of the teacher. Currently, implementing information, computer and technology (ICT) in teaching and learning is a must because humans worldwide have considered multiple electronic media as the paramount need. In this disruptive era, the pedagogical system shifts from utilizing ICT for delivering content to helping students be self-regulated learning [1]. The more easy access to technology encourages teachers worldwide to implement a multimodal learning approach [2]. The educational system should adopt a new teaching approach in responding to the rapid development of ICT without abandoning the mainstream teaching and learning approach [3] regardless of the challenges encountered by teachers in utilizing digital media to promote a positive impact on students' achievement [1]. 
Storytelling is one of the first tools for children to communicate and express what they feel early. Storytelling in digital combines art and stories incorporated with audiovideo, picture, graphic tools [4]. It could be beneficial for educational purposes [5] to attract students' interest when applied as a learning media [3]. The comic has been well known as an approach for providing stories for children and utilized in several subjects, including mathematics [6] and others [7], [8]. The comic is a potential tool to support a better learning environment [3]. The comic has been applied for educational purposes and proved in strengthening and supporting students' literacy skills [9], discussing difficult vocabularies [10], [11] and is of value to promote required literacy skills [12]-[14], including scientific literacy. A comic's valuable role as a medium for any type of readers (Carter, 2007; Rice, 2012) in educational field has been revealed in empirical and non-empirical evidence [12], [15]. Hutchinson (1949) [16] is recognized as the pioneer in utilizing comics as a learning tool and found that comics encouraged poor readers to be good readers. Following his footstep, many works currently used comic characters in classrooms such as Batman [17] for science, neuroscience and psychology disciplines.

Following the advance of ICT and its invasion in all aspects of life, the comic should be presented preferably for the young generation in the digital platform. The purpose of this research was to find the use of disruptive media based on mobile apps in social learning that can be applied to integrated systems such as LMS or online courses interactively. It is expected to produce media with the help of digital comic technology and AR. The criteria for the mobile apps platform used can support digital comic content and AR comprehensively and can be properly validated for users. The application can facilitate learning with applied science learning content in accelerating the process of accepting learners using innovative multimedia. As a research product implemented in an online learning service system, it is necessary to pay attention to aspects of user acceptance testing to determine the adaptation of personalized learning that is being applied in the future pandemic learning period.

\section{Literature review}

\subsection{Learning media development}

The learning process that only uses textbooks and worksheets that require students to solve problems is certainly not in line with the demands of the 21 st Century, which require human resources to have thinking and problem-solving skills. To develop student skills depends on the teacher in imparting knowledge so that these skills can be developed. A teacher needs to use a learning approach that can train students' creative thinking skills. An interactive learning media as displayed in Figure 1. 


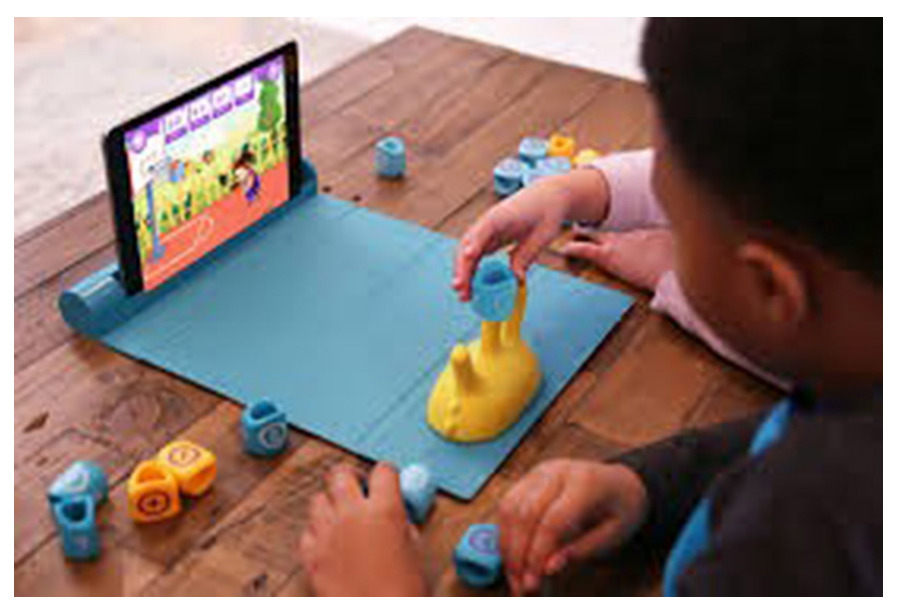

Fig. 1. Interactive learning media

Learning science by integrating interactive media in science, technology, engineering, and mathematics has a big impact on academic achievement [18]. If it is associated with the environment, media can be developed to create learning that presents the real world experienced by students in everyday life [19]. This means that through the scientific innovation approach, students are not just memorizing concepts but also how they understand science concepts and their relation to everyday life.

Apart from developing knowledge content in science, technology, engineering and mathematics, science innovation integration education also seeks to cultivate scientific inquiry and problem-solving skills. Train problem-solving skills supported by scientific behaviour, then science innovation integration education seeks to build a society aware of the importance of media literacy. Media literacy refers to an individual's ability to understand how intense competition works in the real world, which requires four interrelated domains. In this study, an integrated science innovation approach aims to remove the dividing wall between each field of science and teach students as a subject [20].

\subsection{Disruptive learning through AR/VR media}

Information and Communication Technology (ICT) is a tool or method used by humans to convey, Augmented Reality (AR) is a type of technology development that is engaged in the digital (virtual) field, which combines two-dimensional and or three-dimensional virtual objects into a three-dimensional real environment and then projects these virtual objects in the real environment. AR development has so far been widely applied in learning media in various scientific fields. 


\section{$3 \quad$ Method}

\subsection{The procedure in developing digital comic media}

The digital comic media in this study was developed according to the Research and Development (R\&D) procedure proposed by Gay (1990) [21] with the following steps.

a. Literature study

This step involved the searching of relevant pieces of literature of the science contents and the digital aspect for developing the digital comic

b. Planning

This step identifies all the needs to develop the digital comic media (need assessment), including the hardware and software to create the digital comic, the budget, and others.

c. Development and validation of the prototype

This step involved digital media and science experts in providing feedback regarding the digital aspect and science content of the digital comic.

d. Initial test of the prototype

This step involved 50 respondents from several secondary schools in east java, Indonesia

e. Revising prototype 1

f. Empirical test

This step involved 300 respondents from 10 secondary schools in east java, Indonesia

g. Refining the final product

h. Dissemination and implementation

\subsection{Data analysis}

The quality of the Digital Comic Media was measured based on the assessment provided by the participant at the empirical test. In addition, students' visual ability was also measured after implementing the media.

\section{$4 \quad$ Results and discussion}

\subsection{The brief description of the digital comic media}

The example of displayed sides of the comic media produced is shown in Figure 2. The contents are in the area of general sciences, which are relevant to secondary school students. By clicking one of the topics (nature \& environment, galaxy \& solar system, marine life), a student will explore the relevant content covering the complete explanation of the topic enriched with augmented reality technology. The explanations of each concept were mainly displayed in the form of a comic. 


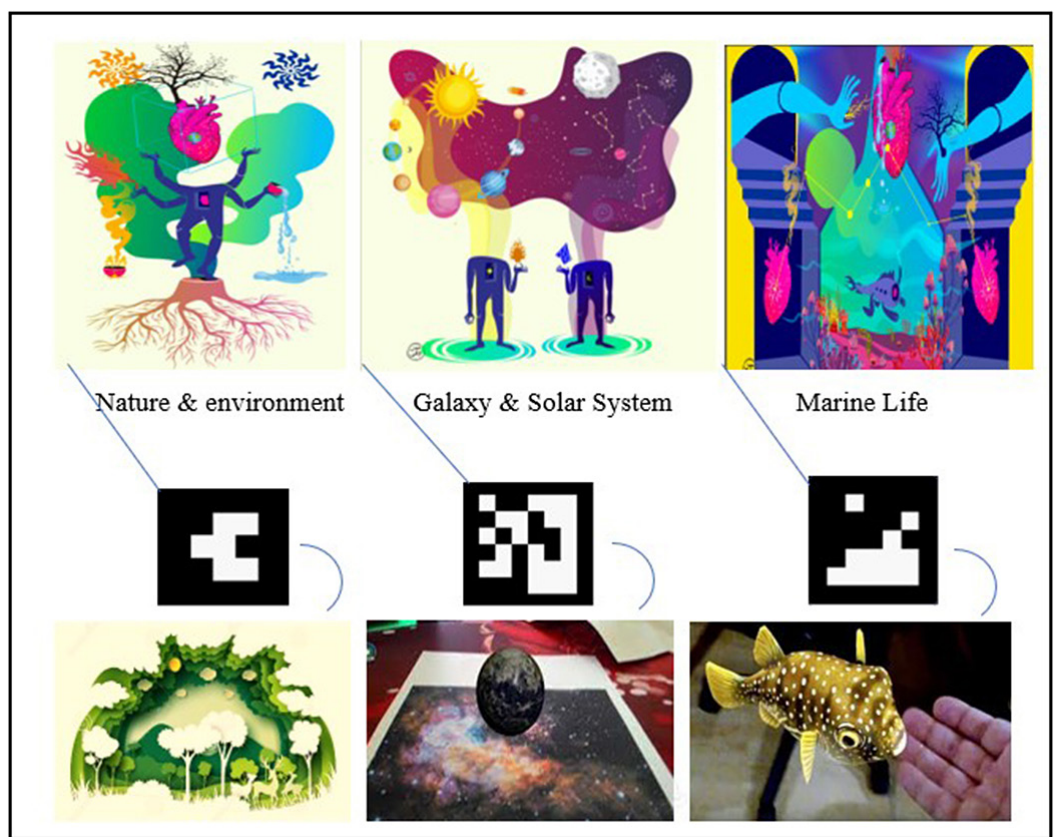

Fig. 2. Series comic digital for science

Figure 3 below presents the display of the digital comic when the feature of "galaxy \& solar system" (Figure 2) is clicked. Students will explore the explanation of solar system concepts accompanied by a picture and 3D animation. This feature is expected to attract students' interest and motivation and strengthen their understanding of the related concepts.

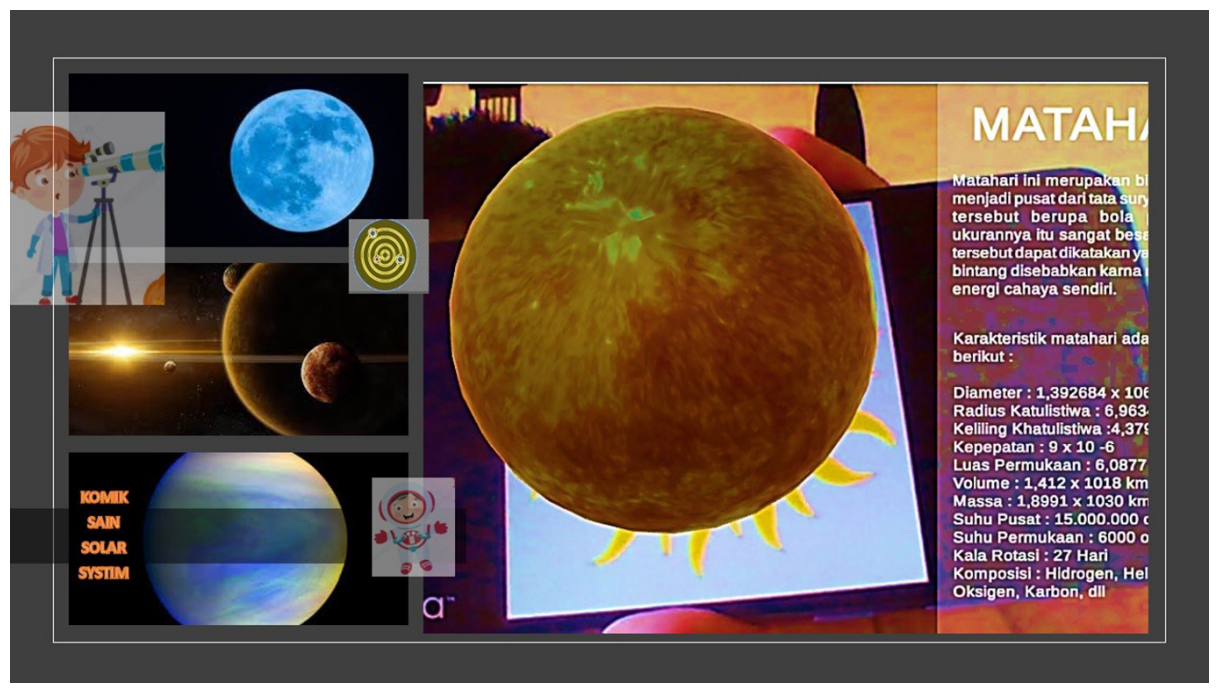

Fig. 3. Solar cell comic 


\subsection{Respond of the participants}

Respond of participants (Table 1) regarding the digital comic media was measured in four categories: personalized learning, motivation, usability, and media attractiveness. Students' responses to the media were satisfied, as shown in Table 1. Three criteria (personalized learning, usability and attractiveness) were considered very good with many students. In the aspect of motivation, most students provided an excellent category for the media.

Table 1. Respond of the participants regarding the digital comic media

\begin{tabular}{|l|c|c|c|c|}
\hline \multicolumn{1}{|c|}{ Score } & Personalized Learning & Motivation & Usability & Attractiveness \\
\hline Category & Very good & Excellent & Very good & Very good \\
\hline $\mathrm{N}(\%)$ & $86.81 \%$ & $91.50 \%$ & $84.72 \%$ & $89.24 \%$ \\
\hline Average & \multicolumn{4}{|c}{} \\
\hline
\end{tabular}

These responses strengthen the previously published work that comic-based digital storytelling facilitated effective teaching and is also easy to be applied in teaching and learning [5], attracted students' attention and helped teacher in presenting the material in an interesting manner [6], improve students technological literacy and creativity [7].

\section{Conclusion}

The study showed that students provided a positive response to digital comic media. However, the effectiveness of this media in improving students' ability towards science concepts and their soft skills need to be further explored.

\section{Acknowledgment}

We thank Universitas Negeri Malang for providing the grant to do this research under the PNBP UM Scheme 2020. We also thanks PUI PT Disruptive Learning Innovation who facilitate the continuation of this research map.

\section{$7 \quad$ References}

[1] J. G. Hedberg, "Towards a disruptive pedagogy: changing classroom practice with technologies and digital content," EMI. Educ. Media Int., vol. 48, no. 1, pp. 1-16, Mar. 2011, doi: https://doi.org/10.1080/09523987.2011.549673

[2] J. A. Watson and L. L. Pecchioni, "Digital natives and digital media in the college classroom: assignment design and impacts on student learning," EMI. Educ. Media Int., vol. 48, no. 4, pp. 307-320, Dec. 2011, doi: https://doi.org/10.1080/09523987.2011.632278

[3] S. Maria, F. Sofos, and D. Mouzaki, "Digital Storytelling, comics and new technologies in education: review, research and perspectives," Int. Educ. J. Comp. Perspect., vol. 17, no. 4, pp. 97-112, 2018. 
[4] B. R. Robin, "Digital storytelling: a powerful technology tool for the 21 st century classroom," Theory Pract., vol. 47, no. 3, pp. 220-228, Jul. 2008, doi: https://doi. org $/ 10.1080 / 00405840802153916$

[5] C. B. Rutta, G. Schiavo, M. Zancanaro, and E. Rubegni, "Comic-based digital storytelling for content and language integrated learning," EMI. Educ. Media Int., vol. 58, no. 1, pp. 21-36, Jan. 2021, doi: https://doi.org/10.1080/09523987.2021.1908499

[6] O. Faruk Islim, G. Ozudogru, and N. Sevim-Cirak, "The use of digital storytelling in elementary Math teachers' education," EMI. Educ. Media Int., vol. 55, no. 2, pp. 107-122, Apr. 2018, doi: https://doi.org/10.1080/09523987.2018.1484045

[7] E. Rubegni and M. Landoni, "Fiabot! design and evaluation of a mobile storytelling application for schools," in Proceedings of the 2014 Conference on Interaction Design and Children, 2014, pp. 165-174, doi: https://doi.org/10.1145/2593968.2593979

[8] G. Y. Choi, "Learning through digital storytelling: exploring entertainment techniques in lecture video," EMI. Educ. Media Int., vol. 55, no. 1, pp. 49-63, Jan. 2018, doi: https://doi. org/10.1080/09523987.2018.1439710

[9] A. K. Dallacqua, "Reading comics collaboratively and challenging literacy norms," Lit. Res. Instr., vol. 59, no. 2, pp. 169-190, Apr. 2020, doi: https://doi.org/10.1080/19388071. $\underline{2019.1669746}$

[10] J. N. Burgoon, M. L. Heddle, and E. Duran, "Re-examining the similarities between teacher and student conceptions about physical science," J. Sci. Teacher Educ., 2011, doi: https:// doi.org/10.1007/s10972-010-9196-x

[11] R. Versaci, "How comic books can change the way our students see literature: one teacher's perspective," English J., vol. 91, no. 2, pp. 61-67, 2001. https://doi.org/10.2307/822347

[12] J. B. Carter, Building Literacy Connections with Graphic Novels: Page by Page, Panel by Panel. Urbana: National Council of Teachers of English, 2007.

[13] N. Frey and D. Fisher, Teaching Visual Literacy: Using Comic Books, Graphic Novels, Anime, Cartoons, and More to Develop Comprehension and Thinking Skills. Thousand Oaks, CA: Corwin Press, 2008.

[14] S. McCloud, Understanding Comics: The Invisible Art. New York: Harper Perennial, 1993.

[15] D. E. Low, "'Spaces invested with content': crossing the 'gaps' in comics with readers in schools," Child. Lit. Educ., vol. 43, no. 4, pp. 368-385, 2012, doi: https://doi.org/10.1007/ s10583-012-9172-5

[16] K. H. Hutchinson, "An experiment in the use of comics as instructional material," J. Educ. Sociol., vol. 23, no. 4, pp. 236-245, Sep. 1949, doi: https://doi.org/10.2307/2264559

[17] E. P. Zehr, "From Claude Bernard to the Batcave and beyond: using Batman as a hook for physiology education," Adv. Physiol. Educ., vol. 35, no. 1, pp. 1-4, Mar. 2011, doi: https:// doi.org/10.1152/advan.00120.2010

[18] K. H. Becker and K. Park, "Integrative approaches among science, technology, engineering, and mathematics (STEM) subjects on students learning: a meta-analysis," J. STEM Educ., vol. 12 , no. 5, pp. 23-37, 2011.

[19] M. M. Subramaniam, J. Ahn, K. R. Fleischmann, and A. Druin, "Reimagining the role of school libraries in STEM education: creating hybrid spaces for exploration," Libr. Q., vol. 82, no. 2, pp. 161-182, Apr. 2012, doi: https://doi.org/10.1086/664578

[20] J. M. Breiner, S. S. Harkness, C. C. Johnson, and C. M. Koehler, "What is STEM? a discussion about conceptions of STEM in education and partnerships," Sch. Sci. Math., vol. 112, no. 1, pp. 3-11, Jan. 2012, doi: https://doi.org/10.1111/j.1949-8594.2011.00109.x

[21] L. R. Gay, Educational Evaluation and Measurement: Competencies for Analysis and Application, 2nd Edition. New York: Pearson, 1990. 


\section{Authors}

Habiddin Habiddin, Department of Chemistry, Universitas Negeri Malang, Malang, Indonesia.

Muhammad Ashar, PUIPT Disruptive Learning Innovation, Universitas Negeri Malang, Malang, Indonesia.

Achmad Hamdan, Department of Electrical Engineering, Universitas Negeri Malang, Malang, Indonesia.

Khaidir R Nasir, Department of Electrical Engineering, Universitas Negeri Malang, Malang, Indonesia.

Article submitted 2021-11-19. Resubmitted 2021-12-27. Final acceptance 2022-01-09. Final version published as submitted by the authors. 